\title{
Nuclear $\beta$-catenin expression is closely related to ulcerative growth of colorectal carcinoma
}

\author{
JM Chiang, ${ }^{* 1,2}$, YH Wu Chou ${ }^{1,2}$, TC Chen $^{1,2}$, KF Ng $^{1,2}$ and JL Lin ${ }^{1,2}$ \\ 'Division of Colon and Rectal Surgery, Human Molecular Genetics Laboratory, Chang Gung Memorial Hospital, 199 Tung Hwa North Road, Taipei, Taiwan \\ 333; ²Department of Pathology, Chang Gung Memorial Hospital, 199 Tung Hwa North Road, Taipei, Taiwan 333
}

\begin{abstract}
Although most colorectal cancer develops based on the adenoma-adenocarcinoma sequence, morphologically, colorectal cancer is not a homogeneous disease entity. Generally, there are two distinct morphological types: polypoid and ulcerative colorectal tumours. Previous studies have demonstrated that K-ras codon 12 mutations are preferentially associated with polypoid growth of colorectal cancer; however, little is known about the molecular mechanism that determines ulcerative growth of colorectal cancer. $\beta$-catenin complex plays a critical role both in tumorigenesis and morphogenesis. We examined the differential expression of $\beta$-catenin and its related factors among different types of colorectal cancer in order to determine any relationship with gross tumour morphology. Immunohistochemical staining of $\beta$-catenin, E-cadherin and MMP-7 was performed on $5 \mathrm{I}$ tumours, including 26 polypoid tumours and 25 ulcerative tumours. Protein truncation tests and single-strand conformational polymorphism for mutation of the adenomatous polyposis coli tumour suppressor gene, as well as singlestrand conformational polymorphism for the mutation of $\beta$-catenin exon 3 were also done. Nuclear expression of $\beta$-catenin was observed in 18 out of 25 (72\%) cases of ulcerative colorectal cancer and seven out of $26(26.9 \%)$ cases of polypoid colorectal cancer. A significant relationship of nuclear $\beta$-catenin expression with ulcerative colorectal cancer was found $(P<0.00 \mathrm{I})$. However, this finding was independent of adenomatous polyposis coli tumour suppressor gene mutation and $\mathrm{E}$ cadherin expression. Together with previous data, we propose that different combinations of genetic alterations may underlie different morphological types of colorectal cancer. These findings should be taken into consideration whenever developing a new genetic diagnosis or therapy for colorectal cancer.
\end{abstract}

British Journal of Cancer (2002) 86, I 124- I 129. DOI: 10.1038/sj/bjc/66002I4 www.bjcancer.com

(C) 2002 Cancer Research UK

Keywords: $\beta$-catenin; colorectal cancer; polypoid tumour; ulcerative tumour; carcinogenesis

Colorectal carcinogenesis involves a multistep progression of genetic mutations. Based on the adenoma-carcinoma sequence, much research has focused on mutation detection; sequential genetic alterations have been illustrated as a linear process (Fearon and Vogelstein, 1990; Kinzler and Vogelstein, 1996). Although this approach represents a well-known paradigm for the sequential development of cancer driven by the accumulation of genetic defects, more and more cases of carcinogenesis have been reported in contrast to the linear and clonal development of cancer (Sedivy et al, 2000). Recently, a non-linear, chaodynamic model of carcinogenesis has been suggested by others. In this model, genetic instability among cells produces a tremendous and chaotic diversity that may lead to cancer (Coffey, 1998). Furthermore, from a holistic point of view, not only genetic events may drive the onset of cancer. In biology, deterministic and non-deterministic phenomena coexist. Clinically, in terms of gross morphology, colorectal cancer (CRC) is not a homogeneous disease entity (Kudo, 1993; Hamilton, 1995; Kato et al, 1997). In general, there are two common but distinct morphological types, namely polypoid and ulcerative colorectal tumours (Hamilton, 1995). These are distinguished by different gross appearances: either an exophytic or endophytic growth pattern (Figure 1). Polypoid tumours always show distin-

*Correspondence: J-M Chiang; E-mail: jmjiang@ms34.hinet.net

Received 30 July 200 I; revised 3 I January 2002; accepted 31 January 2002 guished protruding or exophytic growth towards the bowel lumen (Figure 1A). Ulcerative tumours have an ulcer that usually exhibits endophytic growth toward the bowel wall itself; thus the tumour's floor may be below the surface of the surrounding mucosa (Figure 1B). These divergent morphological features lead us to question whether different genetic or different combinations of genetic alterations are what are involved in colorectal carcinogenesis.

In the model proposed by Vogelstein et al (1988), adenomatous polyposis coli (APC) tumour suppressor gene mutation is found in the earliest stage, before proceeding to K-ras mutation as well as to other tumour suppressor genes, such as p53 and DCC. Paralleling increases in adenoma size and grade of dysplasia ensue during colorectal tumour progression. However, nothing has been described on whether different genetic alterations occurred between these two distinct types of colorectal cancer during multistep carcinogenesis. Although data from synchronous adenoma and carcinoma analyses emphasised that the accumulation of genetic alterations is more important than their order (Fearon and Vogelstein, 1990; Kinzler and Vogelstein, 1996), some researchers are still interested in establishing an ideal linear process. Nonetheless, there are reports indicating that the significantly low frequency of K-ras mutation is associated with superficial or non-polypoid type colorectal adenoma or carcinoma (Yamagata et al, 1994, 1995). Others and we have further demonstrated significant correlation between polypoid growth of CRC and K-ras codon 12 mutation (Chiang et al, 1998). However, with regard to the ulcerative type of color- 
A

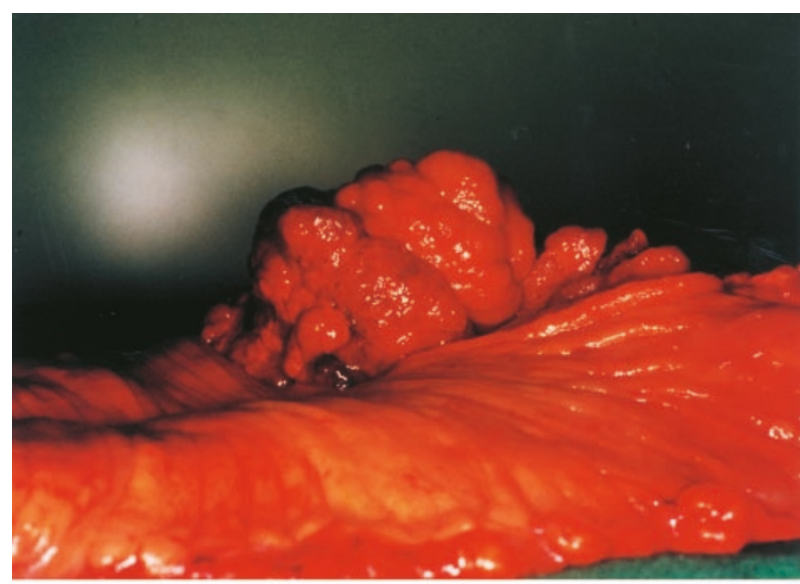

B

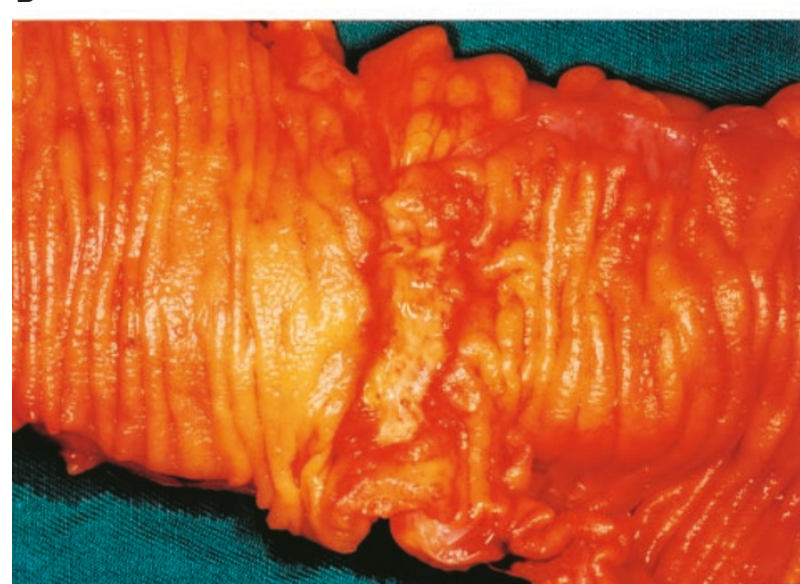

Figure I (A) polypoid tumour; (B) ulcerative tumour.

ectal cancer, this remains poorly understood. We investigated the expression of $\beta$-catenin, which plays an important role in the morphogenesis and carcinogenesis of colorectal cancer (Gumbiner, 1996). Apart from its involvement in cell adhesion and the Wingless/Wnt signaling pathway, $\beta$-catenin may play a direct role in colorectal carcinogenesis because it binds the products of the APC tumour suppressor gene. When APC is mutated, which occurs in up to $80 \%$ of colorectal cancer, $\beta$-catenin accumulates and translocates to the nucleus, where it binds the transcription factors of the TCF/LEF gene family and activates the expression of target genes (Korinek et al, 1997).

We attempted to detect if any differential expression of $\beta$-catenin was related to different morphological growth patterns in colorectal carcinomas. Factors related to altered $\beta$-catenin expression including E-cadherin expression, mutations of the APC tumour suppressor gene or the $\beta$-catenin gene itself were also investigated. Materialising matrix metalloproteinase-7 (MMP-7) expression, one of the downstream targets of $\beta$-catenin, was also analysed in relation to $\beta$-catenin expression.

\section{MATERALS AND METHODS}

\section{Sample collection}

We collected 51 primary colorectal carcinoma tissue samples from sporadic colorectal cancer patients who underwent colectomies at Chang Gung Memorial Hospital (CGMH). All samples were collected immediately after resection and stored in a $-80^{\circ} \mathrm{C}$ freezer. Normal mucosa samples were removed at the same time from sites about $10 \mathrm{~cm}$ from each tumour. Whole tumour specimens were then prepared for routine histopathological examination. Formalin-fixed, paraffin-embedded colorectal carcinoma tissue samples were preserved in the tissue archives of the Pathology Department at CGMH.

Detailed morphological descriptions, histopathological data and clinical data were obtained for each case from the Cancer Registry of the Department of Colorectal Surgery at CGMH.

Tumours with exophytic cauliflower-like appearances with or without a very shallow ulcer only, and with a height exceeding half their diameter, were classified as polypoid (Figure 1A). Tumours within depressed ulcers with or without very low elevated edges, and showing endophytic growth, were classified as ulcerative (Figure 1B).

\section{Immunohistochemistry}

Standard immunohistochemical detection with minor modifications was performed on sections from the archival, paraffinembedded tissue to detect E-cadherin, $\beta$-catenin and matrilysin proteins.

Five-micron sections mounted onto slides were deparaffinised and rehydrated in graded alcohols and distilled water. Endogenous peroxidase activity was inhibited by incubation with $3 \%$ hydrogen peroxide in methanol for $20 \mathrm{~min}$. Antigen retrieval was done by microwaving at high power for two cycles of 5 min each, with a 10-min break between cycles in citrate buffer at $\mathrm{pH}$ 6.0. Non-specific binding of secondary antibodies was blocked by incubation in $10 \%$ normal rabbit serum.

Incubations with primary antibodies were done at $37^{\circ} \mathrm{C}$ for $120 \mathrm{~min}$ for anti E-cadherin (Transduction Laboratories, Lexington, KY, USA) at $100 \times$ dilution, $60 \mathrm{~min}$ at $37^{\circ} \mathrm{C}$ for anti- $\beta$ catenin (Transduction Laboratories) at $200 \times$ dilution and 1:300 for MMP-7 (Chemicon, Hofhem, Germany). After three washes with phosphate buffered saline (PBS), the slides were incubated with biotinylated antimouse immunoglobulin and stained using the Ultra Tech Detection System Kit (Immunotech, Cedex, France). 3,3' Diaminobenzidine (DAB) was used as the chromogen. The slides were counterstained with hematoxylin and dehydrated in graded alcohols, air-dried and mounted using a resin-based mounting medium (Immunotech) under coverslips.

\section{Stain interpretation}

Slides were independently examined by two experienced observers (JM Chiang and KF Ng) who were blind to the clinicopathological data of the tumour and to the initial results of the other observer. In areas of well-preserved tissue, the staining intensity of the cell membrane or cytoplasm was evaluated using the staining of adjacent non-involved normal mucosa as the internal control for each section. Membrane expression of E-cadherin or $\beta$-catenin was considered preserved when staining of cancer cells was as strong as that of normal glands, and the proportion of positive cancer cells in each section was more than $90 \%$. If there was identifiable positive staining in less than $10 \%$ of the cancer cells, the tumours were recorded as having a loss of E-cadherin or $\beta$-catenin membrane expression. Nuclear staining of positive cells was defined as an intense brown colour in the nucleus (Figure 2). The pattern of nuclear staining was defined as follows: negative group, no less than $5 \%$ scattered positive cells without any clusters; focal group, positive cells clustered in focal areas, when $>5 \%$, but $<50 \%$ of the nuclei were stained; diffuse, over-expressed group, positive cells distributed diffusely, homogeneously or heterogeneously, when $\geqslant 50 \%$ of the nuclei were stained. 
A

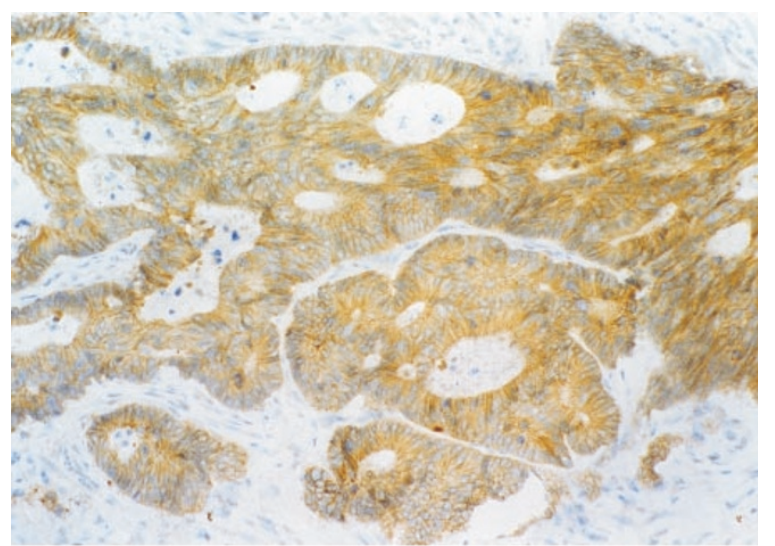

B

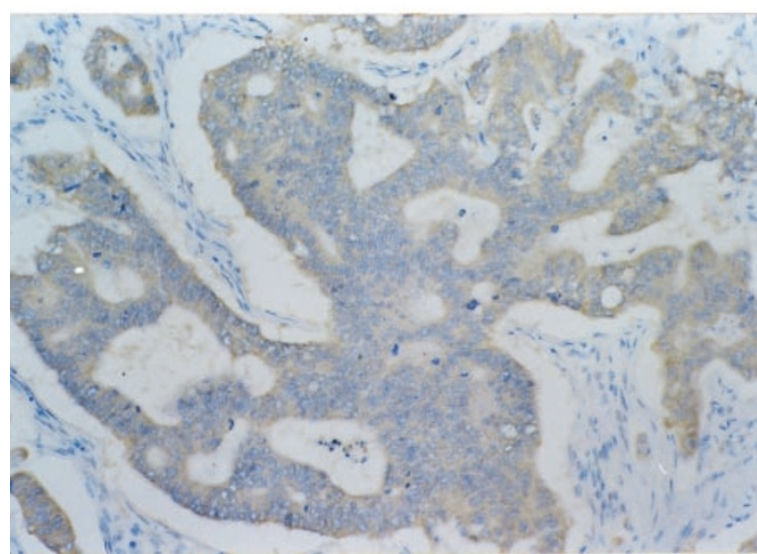

C

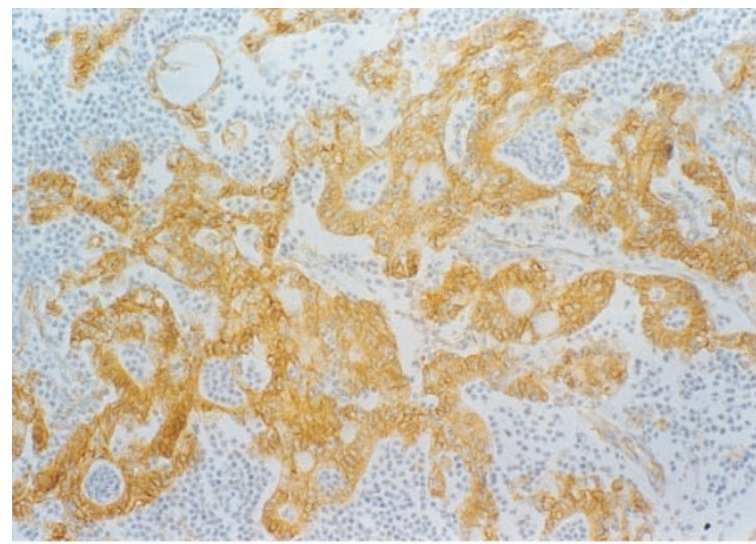

D

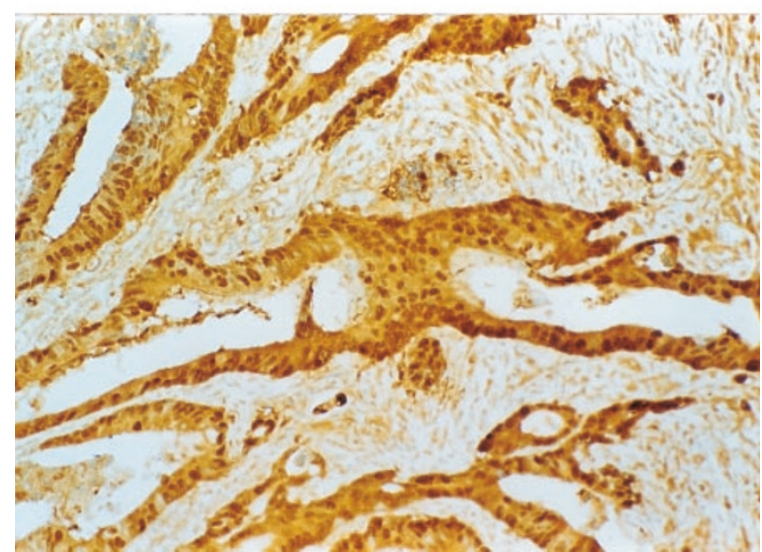

E

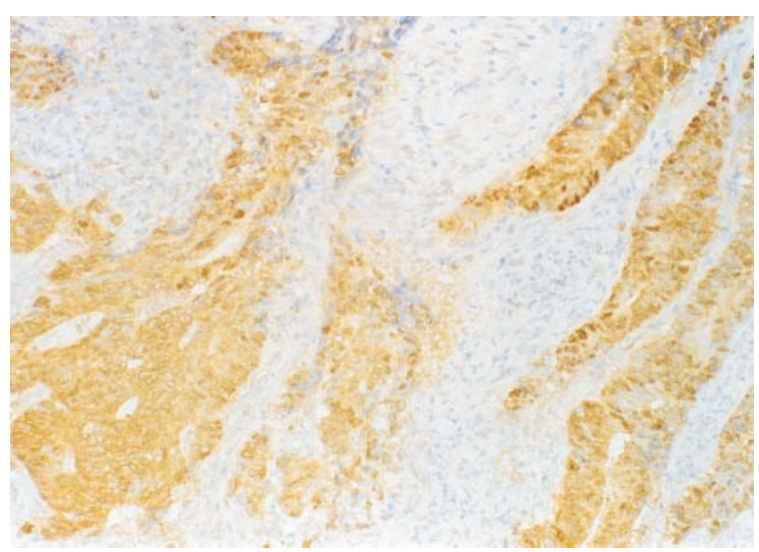

Figure 2 Representative immunohistochemical staining of E-cadherin and $\beta$-catenin in resected colon specimens from sporadic CRC: (A) E-cadherin and (C) $\beta$-catenin are mainly localised at the membranes of the cell-to-cell borders (preserved, paraffin-embedded colorectal carcinoma); (B) loss of membrane staining for E-cadherin. Both (D) and (E) show a loss of membrane staining of $\beta$-catenin with reciprocal change in nuclear $\beta$-catenin expression. (D) Diffuse, widespread nuclear immunostaining for $\beta$-catenin is profound in colon carcinoma cells, while (E) shows focal, clustered nuclear $\beta$-catenin expression. A-E: $\times 400$.

\section{APC and $\beta$-catenin gene mutational analysis}

Genomic DNA from each tumour sample and corresponding normal mucosa was extracted. SSCP analysis of $\beta$-catenin exon 3 was performed using the following primer pair: exon 3, 5'-GATTT-

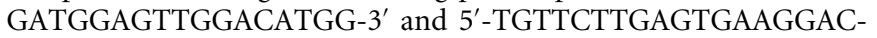
TGAG-3'. Samples were amplified through 35 cycles on a thermocycler (Perkin-Elmer) at $95^{\circ} \mathrm{C}$ denaturation for $50 \mathrm{~s}, 57^{\circ} \mathrm{C}$ annealing for $30 \mathrm{~s}$ and $72^{\circ} \mathrm{C}$ extension for $10 \mathrm{~min}$. Polymerase chain reaction (PCR) was performed in a volume of $25 \mu \mathrm{l}$ with
20 ng of genomic DNA in a PCR buffer containing $1.5 \mathrm{~mm} \mathrm{MgCl}$, $200 \mu \mathrm{M}$ each deoxyribonucleoside triphosphate, 5 pmol of each primer and 0.5 units of Taq polymerase (Perkin-Elmer, Branchburg, NJ, USA).

For the investigation of the APC gene, exon 15 mutations were performed using the protein truncation test (PTT) on genomic DNA as described previously (Van der Luijt, 1994). Exons 1-14 were screened by SSCP using published oligonucleotides and PCR conditions (Van der Luijt, 1994; Li et al, 1999). After PCR amplification, products were loaded onto $12.5 \%$ polyacrylamide 
gels from a GeneGel Excel 12.5/2.4 kit (Pharmacia Biotech, AB Uppsala, Sweden) and underwent electrophoresis at $20^{\circ} \mathrm{C}$. The single and double strands of the PCR products were visualised by silver staining as described previously.

\section{Statistics}

Comparative data were analysed using the Mann-Whitney $U$-test, the Pearson's correlation coefficient and the chi-square test. A twosided $P<0.05$ was determined as statistically significant.

\section{RESULTS}

We collected 51 colorectal carcinoma samples, including 25 ulcerative tumours and 26 polypoid tumours. The clinicopathological parameters, including age, gender, tumour stage, tumour differentiation and tumour size were comparable between the two groups, except for right colon predominance in the polypoid CRC group and significantly deeper invasion depth in the ulcerative CRC group (Table 1). The difference in depth of invasion between these two groups were mainly reflected in the smallersized $(\leqslant 4 \mathrm{~cm})$ tumour group, while no difference in invasion depth was found for the larger-sized $(>4 \mathrm{~cm})$ tumour group (Table 2).

Regarding $\beta$-catenin and E-cadherin expression by immunohistochemical staining, loss of membrane staining was observed in 23 out of the $51(45 \%)$ and 22 out of the $51(43 \%)$ cases, respectively. Forty-nine per cent (25 out of 51 ) of cases showed nuclear $\beta$-catenin expression and always showed a reciprocal loss of membrane staining except for two preserved cases (Table 3).

Table I Comparisons of clinical and histopathological parameters between ulcerative and polypoid colorectal carcinomas

\begin{tabular}{|c|c|c|c|}
\hline & $\begin{array}{c}\text { Ulcerative } \\
\quad(n=25)\end{array}$ & $\begin{array}{c}\text { Polypoid } \\
(n=26)\end{array}$ & $P$ value \\
\hline Age range (years) & $41-83$ & $29-80$ & \\
\hline Average age (years) & 61.3 & 60.6 & 0.752 \\
\hline $\begin{array}{l}\text { Sex } \\
\text { M/F }\end{array}$ & $17 / 8$ & $14 / 12$ & 0.301 \\
\hline $\begin{array}{l}\text { Tumour location } \\
\text { Right colon } \\
\text { Left colon } \\
\text { Rectum }\end{array}$ & $\begin{array}{r}1 \\
4 \\
20\end{array}$ & $\begin{array}{r}4 \\
12 \\
10\end{array}$ & 0.010 \\
\hline $\begin{array}{l}\text { Duke's stage } \\
\text { A } \\
\text { B } \\
\text { C } \\
\text { D }\end{array}$ & $\begin{array}{r}0 \\
14 \\
9 \\
2\end{array}$ & $\begin{array}{r}4 \\
13 \\
6 \\
3\end{array}$ & 0.186 \\
\hline $\begin{array}{l}\text { Depth of invasion }{ }^{\text {a }} \\
\text { T1 } \\
\text { T2 } \\
\text { T3 }\end{array}$ & $\begin{array}{r}1 \\
19 \\
5\end{array}$ & $\begin{array}{r}8 \\
17 \\
1\end{array}$ & 0.017 \\
\hline $\begin{array}{l}\text { Tumour differentiation } \\
\text { Well } \\
\text { Moderate } \\
\text { Poorly }\end{array}$ & $\begin{array}{r}5 \\
20 \\
0\end{array}$ & $\begin{array}{r}9 \\
15 \\
2\end{array}$ & 0.147 \\
\hline $\begin{array}{l}\text { Tumour histology } \\
\text { Adenocarcinoma } \\
\text { Mucinous adenocarcinoma }\end{array}$ & $\begin{array}{r}22 \\
3\end{array}$ & $\begin{array}{r}21 \\
5\end{array}$ & 0.457 \\
\hline $\begin{array}{l}\text { Tumour size } \\
\begin{array}{c}<3 \mathrm{~cm} \\
3-5 \mathrm{~cm} \\
>5 \mathrm{~cm}\end{array}\end{array}$ & $\begin{array}{r}7 \\
12 \\
6\end{array}$ & $\begin{array}{r}5 \\
16 \\
5\end{array}$ & 0.614 \\
\hline
\end{tabular}

aTI: Tumour invades submucosa; T2: Tumour invades muscularis propria; T3: Tumour invades through the muscularis propria into the subserosa.
There was no significantly different expression of E-cadherin found between polypoid and ulcerative groups. However, a significant difference in membrane $\beta$-catenin staining was found between ulcerative (17 out of $25,68 \%$ ) and polypoid (six out of $26,23 \%)$ groups. A significant difference in nuclear expression of $\beta$-catenin $(P=0.001)$ was also observed between the ulcerative (18 out of $25,72 \%$ ) and polypoid (seven out of 26) groups of CRC (Table 3) when we defined more than $25 \%$ of cells with nuclear $\beta$-catenin expression as positive, and negative was defined as expression in less than $25 \%$ of the cells. Nonetheless, nuclear $\beta$-catenin expression was typically heterogenous; we, therefore, analysed the extent of nuclear $\beta$-catenin expression with relation to these two distinct morphological types of CRC. We found a significant difference between polypoid and ulcerative types of CRC. However, we did not find a significant difference related to the depth of invasion or the location of the tumour (Table 4).

The frequency of APC mutations was 39 out of 51 (76\%) cases. Among the 39 mutations found, 34 were detected in exon 15 truncated proteins (Figure 3), two mutations were found in exon 12, one in exon 10 and one in exon 6. Nineteen out of $25(76 \%)$ APC mutations were found in polypoid tumours and 20 out of $26(77 \%)$ were found in ulcerative tumours (Table 3$)$. No $\beta$-catenin exon 3 mutation was detected in this study.

Nuclear $\beta$-catenin expression was analysed in relation to its related factors. There were no correlations found among nuclear $\beta$-catenin expression and APC gene mutations (Table 5). In addi-

Table 2 Comparisons of invasion depth between polypoid and ulcerative colorectal cancer

\begin{tabular}{lccc}
\hline & Polypoid & Ulcerative & P value \\
\hline Tumour size $\leqslant 4 \mathrm{~cm}$ & & & \\
T1 & 6 & 1 & \\
T2 & 5 & 10 & \\
T3 & 0 & 3 & 0.018 \\
Tumour size $>4 \mathrm{~cm}$ & & & \\
T1 & 2 & 0 & \\
T2 & 12 & 9 & \\
T3 & 1 & 2 & 0.333 \\
\hline
\end{tabular}

Table 3 Comparisons of APC mutation and expression of $\beta$-catenin and E-cadherin between ulcerative and polypoid colorectal carcinoma

\begin{tabular}{|c|c|c|c|}
\hline & $\begin{array}{l}\text { Ulcerative } \\
\quad(n=25)\end{array}$ & $\begin{array}{c}\text { Polypoid } \\
(n=26)\end{array}$ & $P$ value \\
\hline \multicolumn{4}{|c|}{ Nuclear $\beta$-catenin expression ${ }^{\mathrm{a}}$} \\
\hline+ & 18 & 7 & \\
\hline- & 7 & 19 & 0.001 \\
\hline \multicolumn{4}{|c|}{ Membranous $\beta$-catenin expression ${ }^{\mathrm{b}}$} \\
\hline+ & 8 & 20 & \\
\hline- & 17 & 6 & 0.001 \\
\hline \multicolumn{4}{|c|}{ Membranous E-cadherin expression ${ }^{c}$} \\
\hline+ & 15 & 14 & \\
\hline- & 10 & 12 & 0.626 \\
\hline \multicolumn{4}{|c|}{ APC mutation } \\
\hline+ & 19 & 20 & \\
\hline- & 6 & 6 & 0.843 \\
\hline \multicolumn{4}{|c|}{$\beta$-catenin exon 3 mutation } \\
\hline+ & 0 & 0 & \\
\hline - & 25 & 26 & \\
\hline
\end{tabular}

${ }^{a}$ Nuclear $\beta$-catenin expression was defined as positive $(+)$ whenever more than $25 \%$ of the cells showed nuclear $\beta$-catenin expression. ${ }^{b} N u c l e a r ~ \beta$-catenin expression was reciprocal with the loss of membrane $\beta$-catenin expression, except in two cases showing preserved $(+)$ membrane staining. ${ }^{c}+$ means preserved, - means loss of membrane staining. 
Table 4 Relationship between nuclear expression of $\beta$-catenin and histopathology of colorectal cancers

\begin{tabular}{|c|c|c|c|c|c|}
\hline & \multicolumn{5}{|c|}{ Nuclear $\beta$-catenin expression } \\
\hline & \multirow{2}{*}{$\begin{array}{c}\text { Negative } \\
<\mathbf{5 \%}\end{array}$} & \multicolumn{2}{|c|}{ Focal } & \multirow{2}{*}{$\begin{array}{c}\text { Diffuse } \\
\geqslant \mathbf{5 0} \%\end{array}$} & \multirow[b]{2}{*}{$P$ value } \\
\hline & & $5-24 \%$ & $25-49 \%$ & & \\
\hline \multicolumn{6}{|c|}{ Gross morphology } \\
\hline Polypoid & 7 & 12 & 7 & 0 & \\
\hline Ulcerative & 2 & 5 & II & 7 & 0.001 \\
\hline \multicolumn{6}{|c|}{ Depth of invasion } \\
\hline $\mathrm{TI}$ & 2 & 4 & 3 & 0 & \\
\hline $\mathrm{T} 2$ & 7 & | | & 13 & 5 & \\
\hline T3 & 0 & 2 & 2 & 2 & 0.607 \\
\hline \multicolumn{6}{|c|}{ Tumour location } \\
\hline Right colon & I & 1 & 2 & । & \\
\hline Left colon & । & 7 & 8 & 0 & \\
\hline Rectum & 7 & 9 & 8 & 6 & 0.490 \\
\hline
\end{tabular}

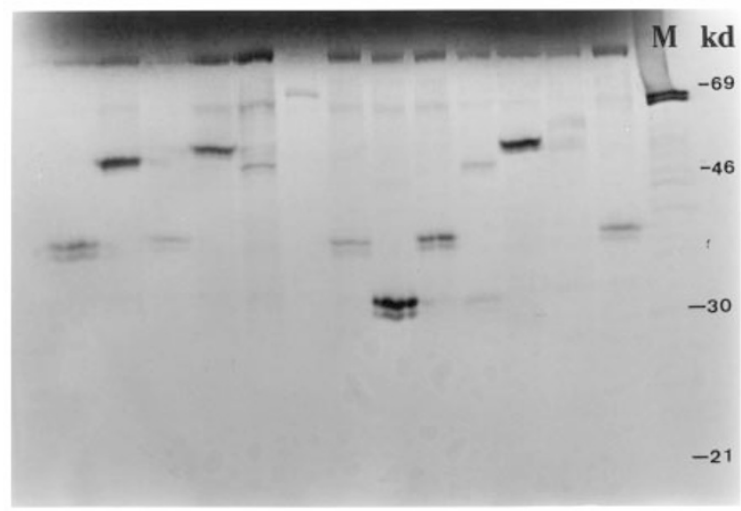

Figure 3 Protein truncation test for APC. Each lane represents the in vitro protein synthesis results of patients with sporadic colon cancer. Note that in several patients extra bands can be seen due to varied sized truncated protein. Size-fractionated on a 10\% SDS-polyacrylamide gel. Lane $M$ is luciferase as molecular weight marker. Size marker (right) is in kilodaltons $(\mathrm{kd})$.

Table 5 Correlation between nuclear $\beta$-catenin expression and APC mutation, E-cadherin expression and MMP-7 expression

\begin{tabular}{lrcc}
\hline & \multicolumn{3}{c}{ Nuclear $\beta$-catenin expression } \\
\cline { 2 - 4 } & $\boldsymbol{+}$ & - & P value \\
\hline APC & 17 & 17 & \\
+ & 8 & 9 & 0.483 \\
- & & & \\
E-cadherin expression & 15 & 14 & 0.848 \\
+ & 11 & 11 & \\
- & & & \\
MMP-7 expression & 3 & 8 & 0.103 \\
+ & 22 & 18 & \\
- & & & \\
\hline
\end{tabular}

tion, loss of E-cadherin expression was not significantly related to nuclear $\beta$-catenin expression. Twenty-two per cent (11 out of 51 ) of the cases demonstrated positive matrilysin (MMP-7) staining, and were observed in all eight mucinous colorectal carcinomas, one in poorly differentiated CRC and the other two in well differentiated CRC. Nonetheless, of these 11 cases, only three demonstrated nuclear $\beta$-catenin expression.

\section{DISCUSSION}

We clearly demonstrated that nuclear $\beta$-catenin expression was significantly related to ulcerative growth of CRC. This result is comparable to results in a recent report (Aust et al, 2001) describing altered distribution of $\beta$-catenin in ulcerative colitis-related colorectal cancer.

Morphologically, the gross appearance of advanced sporadic CRC is quite variable. It is usually difficult to categorise all tumours into either the polypoid or ulcerative groups because intermediate or mixed types showing variable amounts of both components can be found. Other less frequently encountered types are flat or plateau tumours or the rare pipe-like shaped (linitis plastica) tumours. This striking diversity in the gross appearance of CRC may reflect the underlying chaotic genetic instability. In our study, we investigated purely polypoid and purely ulcerative tumours. The implications of our findings are further discussed below.

Contradictory to previous studies showing that K-ras codon 12 mutation is selectively related to polypoidal growth of CRC (Yamagata et al, 1994; Chiang et al, 1998), our study indicated that there were different combinations of genetic alterations occurring in morphologically different tumours during colorectal carcinogenesis. Therefore, reports trying to define the sequence or the specific sites of genetic alterations during multi-step colorectal carcinogenesis should be very carefully considered because the same combinations of genetic alterations may not always be accumulated among the morphological types of CRC. Our findings highlight that future development of responsible genes for gene therapy or genetic diagnosis for CRC may need to be individualised.

Although many in vitro studies using cell lines have proven that mutations in the APC tumour suppressor gene occurs in most colorectal cancer and leads to the activation of $\beta$-catenin (Munemitsu et al, 1995; Morin et al, 1997), this probably is not always the case in vivo. In our study, we showed that nuclear $\beta$-catenin expression was independent of APC tumour suppressor gene mutation, as was reported previously (Kobayashi et al, 2000). Furthermore, we did not find any $\beta$-catenin mutation itself. The question follows, therefore, what regulates or forces the nuclear translocation of $\beta$-catenin? Other genetic or epigenetic events may be present for modulating nuclear translocation. Tyrosine phosphorylation of $\beta$-catenin by a biochemical molecule such as intestinal trefoil factor has been reported (Liu et al, 1997). While, retinoic acid (RA) has been shown to decrease the activity of the $\beta$ catenin- lymphoid enhancer binding factor/T-cell factor signalling pathway. RA activity was also independent of APC tumour suppression and ubiquitination-dependent degradation of cytoplasmic $\beta$-catenin (Easwaran et al, 1999).

Although a significant relationship exists between ulcerative CRC and nuclear $\beta$-catenin expression, we did not find a significant increase in the extent of nuclear $\beta$-catenin expression related to the depth of invasion (Table 4 ). These findings indicate that although nuclear $\beta$-catenin expression may determine the ulcerative growth pattern of CRC, the depth of invasion may be determined by several other factors, and might be the result of a more complex process between tumour and stroma interaction. This finding also implies that higher amounts of nuclear $\beta$-catenin expression are probably necessary for the ulcerative growth from the early stage of tumour progression, while lower amounts of nuclear $\beta$-catenin expression may be sufficient to induce polypoid tumour growth (Brabletz et al, 2000). This finding supports a previous observation showing that $\beta$-catenin occurred in the highest concentrations in the invading line of endophytic growth of tumour cells. (Brabletz et al, 1998). Although we found a significant correlation between nuclear beta-catenin expression and ulcerative growth and also observed that most of the ulcerative tumours were rectal carcinomas (Table 1), we did not observe a significant relationship between tumour localisation and nuclear 
on tumour localisation. Furthermore, the small number of cases in this study limited further analysis of whether there are different carcinogenesis pathways in the colon and rectum.

Precisely how nuclear $\beta$-catenin expression confers ulcerative or endophytic growth to CRC remains poorly understood. Further analyses of several downstream factors of the nuclear $\beta$-catenin/ TCF complex, including c-MYC (He et al, 1998), cyclin D1 (Tetsu and McCormick, 1999), gastrin (Koh et al, 2000), PPARS (He et al, 1999) MMP-7 (Brabletz et al, 1999; Crawford et al, 1999) are warranted. Some factors such as $\mathrm{c}-m y c$, cyclin $\mathrm{D}$ and gastrin reportedly relate to tumour proliferation, while others are related to tumour invasion. MMP-7 is regulated by $\beta$-catenin expression (Brabletz et al, 1999) and is a proteolytic enzyme related to tumour invasion. It may well be reasonable to relate proteolysis to ulcerative growth. However, in our study, we did not observe parallel expression between $\beta$-catenin and MMP-7, which is the case in cell culture studies. These negative findings may be explained similarly to other down-regulators such as tumour growth factor (TGF)- $\beta$, which is involved in a more complex process in vivo than in vitro (Gaire et al, 1994).

\section{REFERENCES}

Aust DE, Terdiman JP, Willenbucher RF, Chew K, Ferrell L, Florendo C, Molinaro-Clark A, Baretton GB, Lohrs U, Waldman FM (2001) Altered distribution of beta-catenin, and its binding proteins E-cadherin and APC, in ulcerative colitis-related colorectal cancers. Mod Pathol 14: 29-39

Brabletz T, Herrmann K, Jung A, Faller G, Kirchner T (2000) Expression of nuclear $\beta$-catenin and $\mathrm{C}$-myc is correlated to tumor size but not to proliferative activity of colorectal adenomas. Am J Pathol 156: 865-870

Brabletz T, Jung A, Dag S, Hlubek F, Kirchner T (1999) $\beta$-catenin regulates the expression of matrix metalloproteinase-7 in human colorectal cancer. Am J Pathol 155: 1033-1038

Brabletz T, Jung A, Herrmann K, Gunther K, Hohenberger W, Kirchner T (1998) Nuclear overexpression of the oncoprotein $\beta$-catenin in colorectal cancer is localized predominantly at the invasion front. Pathol Res Pract 194: $701-704$

Chiang JM, Chou WY, Chou TB (1998) K-ras codon 12 mutation determines the polypoid growth of colorectal cancer. Cancer Res 58: 3289-3293

Coffey DS (1998) Self-organization, complexity and chaos: the new biology for medicine. Nat Med 4: 882-885

Crawford HC, Fingleton BM, Rudolph-Owen LA, Heppner Goss KJ, Rubinfeld B, Polakis P, Matrisian LM (1999) The metalloproteinase matrilysin is a target of $\beta$-catenin transactivation in intestinal tumors. Oncogene 18: $2883-2891$

Dean M (1998) Cancer as a complex developmental disorder. Cancer Res 58: $5633-5636$

Easwaran V, Pishvaian M, Salimuddin BS (1999) Cross-regulation of $\beta$-catenin- LEF/TCF and retinoid signaling pathways. Curr Biol 9: 1415-1418

Fearon ER, Vogelstein B (1990) A genetic model for colorectal tumorigenesis. Cell 61: $759-767$

Gaire M, Magbanua Z, McDonnell S, McNeil L, Lovett DH, Matrisian LM (1994) Structure and expression of the human gene for the matrix metalloproteinase matrilysin. J Biol Chem 269: 2032-2040

Gumbiner BM (1996) Cell adhesion: the molecular basis of tissue architecture and morphogenesis. Cell 84: $345-357$

Hamilton SR (1995) Pathologic features of colorectal cancer. In Cancer of the Colon, Rectum, and Anus Cohen AM, Winawer ST, Friedman MA, Gunderson LL (eds) pp 189-191 New York: McGraw-Hill

He TC, Chan TA, Vogelstein B, Kinzler KW (1999) PPARS is an APC-regulated target of nonsteroidal anti-inflammatory drugs. Cell 99: 335-345

He TC, Spark AB, Rago C, Hermeking H, Zawel L, da Costa LT, Morin PJ, Vogelstein B, Kinzler KW (1998) Identification of c-MYC as a target of the APC pathway. Science 281: $1509-1512$

Kato S, Fujii T, Oda Y (1997) Differences of genetic alterations between polypoid, flat and depressed growth-type colorectal cancers. Gastroenterology 112: A589 (abstract)

Kinzler KW, Vogelstein B (1996) Lessons from hereditary colorectal cancer. Cell 87: $159-170$
Finally, the finding that nuclear $\beta$-catenin expression is closely related to ulcerative growth of CRC further supports a previous study that showed analogies between embryonic gastrulation and $\beta$-catenin expression (Kirchner and Brabletz, 2000). Strong, diffuse $\beta$-catenin nuclear expression was observed as necessary for mesenchymal transition of tumour cells that expressed invasion behaviour, while weak nuclear $\beta$-catenin expression was only enough for epithelial transitions responsible for cell proliferation (Kirchner and Brabletz, 2000). The connection of our data and the data from embryonic development, thus, supports the concept that tumorigenesis has the properties of a complex developmental disorder (Dean, 1998).

In summary, we observed that the different combinations of genetic alterations may selectively underlie different types of CRC. Nuclear $\beta$-catenin expression is related to the ulcerative growth patterns of CRC. Although the precise mechanism remains poorly understood, its expression is independent of APC mutation. These observations further highlight the heterogenous nature of CRC, which should be kept in mind when developing a new gene therapy or a new genetic diagnosis for CRC.

Kirchner T, Brabletz T (2000) Patterning and nuclear $\beta$-catenin expression in the colonic adenoma-carcinoma sequence-analogies with embryonic gastrulation. Am J Pathol 157: 1113-1121

Kobayashi M, Honma T, Matsuda Y, Suzuki Y, Narisawa R, Ajioka Y, Asakura $\mathrm{H}$ (2000) Nuclear translocation of beta-catenin in colorectal cancer. Br J Cancer 82: 1689- 1693

Koh TJ, Bulitta CJ, Fleming JV, Dockray GJ, Varro A, Wang TC (2000) Gastrin is a target of the $\beta$-catenin/TCF-4 growth-signaling pathway in a model of intestinal polyposis. J Clin Invest 106: $533-539$

Korinek V, Barker N, Morin PJ (1997) Constitutive transcriptional activation by a beta-catenin-Tcf complex in APC - / - colon carcinoma. Science 275: $1784-1787$

Kudo S (1993) Endoscopic mucosal resection of flat and depressed types of early colorectal cancer. Endoscopy 25: 455-461

Li G, Tamura K, Yamamoto Y, Sashio H, Utsunomiya J, Yamaura T, Shimoyama T, Furayama J (1999) Molecular and clinical study of familial adenomatous polyposis for genetic testing and management. J Exp Clin Cancer Res 18: 519-529

Liu D, el-Harriry I, Karayiannakis AM, Wilding J, Chinery R, Kmiot W, McCrea PD, Gullick WJ, Pignatelli M (1997) Phosphorylation of $\beta$-catenin and epidermal growth factor receptors by intestinal trefoil factor. $L a b$ Invest 77: $557-563$

Morin PJ, Sparks AB, Korinek V, Barker N, Clevers H, Vogelstein B, Kinzler KW (1997) Activation of $\beta$-catenin - Tcf signaling in colon cancer by mutations in $\beta$-catenin or APC. Science (Washington DC) 275: $1787-1790$

Munemitsu S, Albert I, Souza B, Rubinfeld B, Polakis P (1995) Regulation of intracellular $\beta$-catenin levels by the adenomatous polyposis coli (APC) tumor suppressor protein. Proc Natl Acad Sci USA 92: 3046-3050

Sedivy R, Wolf B, Kalipciyan M, Steger GG, Karner-Hanusch J, Mader RM (2000) Genetic analysis of multiple synchronous lesions of the colon adenoma-carcinoma sequence. Br J Cancer 82: 1276-1282

Tetsu O, McCormick F (1999) Beta-catenin regulates expression of cyclin D1 in colon carcinoma cells. Nature 398: $422-426$

van der Luijt R, Khan PM, Vasen H, van Leeuwen C, Tops C, Roest P, den Dunnen J, Fodde R (1994) Rapid detection of translation-terminating mutations at the adenomatous polyposis coli (APC) gene by direct protein truncation test. Genomics 20: $1-4$

Vogelstein B, Fearon ER, Hamilton SR, Kern SE, Preisinger AC, Leppert M, Nakamura Y, White R, Smits AM, Bos JL (1988) Genetic alterations during colorectal tumor development. N Engl J Med 319: 525-532

Yamagata S, Muto T, Uchida Y, Masaki T, Higuchi Y, Sawada T, Hirroka T (1995) Polypoid growth and K-ras codon 12 mutation in colorectal cancer. Cancer (Phila) 75: $953-957$

Yamagata S, Muto T, Uchida Y, Masaki T, Sawada T, Tsuno N, Hirooka T (1994) Lower incidence of k-ras codon 12 mutation in flat colorectal adenomas than in polypoid adenomas. Jap J Cancer Res 85: 147-151 